\title{
Transitioning to Democratic Governance in Guinea
}

\author{
Dominique Bangoura \\ Professor at the Centre for Diplomatic and Strategic Studies, Paris. \\ Lecturer and researcher, University of Abidjan
}

\section{Introduction}

Security sector governance is an unfamiliar topic in Guinea. The subject remains taboo because it is generally left under the purview of the military, the police, men in uniform and the head of state. The reasons for this situation are historical as well as political and relate to the different, successive regimes in Guinea: the civilian dictatorship of Sékou Touré, who led the country from the time of independence until his death (1958 to 1984); the military (1984 to 1990) and authoritarian (1990 to 2008) regimes of General-President Lansana Conté and finally the military dictatorship of Captain Moussa Dadis Camara, who took power on 23 December 2008 and held it until 3 December 2009 when he was removed from power, following an attempt on his life.

Against such a backdrop, it has been difficult to establish the institutional and non-governmental conditions required to bring about change. It was only at the start of 2010, with the accession of General Sékouba Konaté, that a more favourable political environment was created and the first security sector governance and reform policy and stability measures were implemented. Also for the first time, civil society was able to influence the process and their demands were taken into account.

Nevertheless, it was only at the end of the transition, with the election of President Alpha Condé in November 2010 that security sector governance took on its full meaning, particularly as there was strong political will at the

How to cite this book chapter:

Bangoura, D. 2015. Transitioning to Democratic Governance in Guinea. In: Bryden, A and Chappuis, F (eds.) Learning from West African Experiences in Security Sector Governance, Pp. 37-59. London: Ubiquity Press. DOI: http://dx.doi.org/10.5334/ bau.c. License: CC-BY 4.0. 
highest level of state and that the various state and non-state actors were all very keen to pursue these efforts. The question now is whether these promises will be fulfilled during the term of office of the incumbent president.

\section{Security sector governance in Guinea: background}

The place and role of the armed and security forces have varied from one regime to another. Although Sékou Touré was a civilian leader, he established and developed a hard-line form of Marxist style authoritarianism, using and misusing the army, which he did not trust. He preferred to develop the Militia, the armed wing of the single party, which was totally devoted to him. Lansana Conté, who was first and foremost a military leader, used the army as one of the principal tools in seizing and maintaining power. Moussa Dadis Camara, who took power through a military coup détat very quickly used the armed forces to entrench his regime and clamp down on both the political opposition and civilians.

\section{Security sector governance under Sékou Touré (1958-1984).}

Guinea was the first Francophone West African country to attain independence, on 2 October 1958, a few days after the historic "no" in the 28 September referendum proposed by General de Gaulle. ${ }^{1}$

A poorly endowed and politicised armed forces. The Guinean armed forces was created on 1 November 1958. It was made up of volunteers from the colonial army (Horoya 1993a; 1993b). However, not all Guinean soldiers were allowed to join the budding national armed forces and a number of them were denied access for political reasons (Bah 2009). ${ }^{2}$ From the start, the Guinean army made a name for itself on the African continent through the contingent that joined the United Nations Blue Helmets in Congo, as well as their engagement alongside various national liberation movements (Angola, Mozambique, etc.) (Soumah 2004: 162). Nevertheless, under Sékou Touré, the Guinean military was deprived of resources, training, and equipment; some NCOs and officers were trained in eastern European countries and in Cuba. The army was provided with Soviet equipment but remained poorly endowed and badly organised.

There are two reasons that can explain the difficulties encountered by the army. First of all, Sékou Touré did not trust the military, ${ }^{3}$ which had been responsible for organising coup deetats on the African continent and deposing several civilian heads of state. The first president of Guinea thus preferred to concentrate resources on the single party that he established, the Democratic Party of Guinea (Parti démocratique de Guinée - PDG). According to the Guinean journalist and politician, Siradiou Diallo, the party, which was designed to be the guiding institution, the driving force, and the instrument for 
controlling national life, was placed at the summit of the pyramid of government. All other institutions, including the armed forces and the militia, were subordinate to the party and only represented organs of implementation or instruments in the service of the party (Diallo 1986). The PDG was therfore named the party-state, which demonstrates its omnipresent (Bah 2009) and totalitarian nature (Camara 1998: 64). ${ }^{4}$

The regime thus exercised tight control over the military. ${ }^{5}$ In addition, the army was subordinate to the PDG, the ruling party. This conception of the military was to have dire consequences. Strong politicisation of the armed forces led to indiscipline because an overzealous corporal with strong political affiliations, close to the seat of power, could easily question orders from a senior officer and even humiliate the latter. This lack of respect for the hierarchy led to malfunctions because subordinate officers had no respect for the military command structure. The politicisation of the military also led to other consequences at a later stage; it encouraged soldiers to take power (the 1984 and 2008 coup détats) and to challenge the regime (repeated counter-coup attempts and mutinies under Lansana Conté, attempted assassination of Moussa Dadis Camara).

The Militia, a force to exert control beyond the armed forces. Under Sékou Touré, the People's Militia, a powerful paramilitary force, superseded the military. It was designed as a protective shield and to provide close security for the head of state. It was directly answerable to him and served as one of the main instruments of domination, in conjunction with the single party. Its mission was in theory to maintain law and order alongside the police, but in reality it was in charge of keeping watch over the armed forces and controlling the population. It was an armed, political police force that excelled in surveillance, denunciations and arbitrary arrests. Ranks in the militia were the same as in the military. Militia members frequently committed acts of violence against the police, gendarmes and soldiers. This parallel body garnered a lot of hostility from career military personnel, who sometimes spoke out or acted against it, but never succeeded in undermining it. Towards the end of his life, President Sékou Touré had a militia that matched the military in terms of numbers: 10,000 men on either side. The militia was however held in greater esteem.

Under such a regime, no social or political force could have even the slightest oversight or control, outside of the organs of the PDG. Sékou Touré died suddenly on 26 March 1984 from a cardio-vascular attack, leaving behind a country that was totally drained, with overcrowded prisons and countless victims who had died under torture or disappeared. In the absence of a proper count and an independent investigation, the precise number of victims of his regime has never been officially established. A few days later, on 3 April 1984, the military took over power under the leadership of Lansana Conté. After 26 years of civilian dictatorship, the country began an era of military dictatorship. 


\section{Security sector governance under Lansana Conté (1984-2008).}

General Lansana Conté held power for 24 years. Between 1958 and 2008 therefore, Guinea had only two heads of state, one civilian and one military, but both shared a style of governing that used force and violence.

Three periods of governance under Lansana Conté. There are three distinct periods in the regime of Lansana Conté. The first, from 1984 to 1990 is the military period. The military regime dissolved the single party (PDG) and suspended the 1982 Constitution but did not undertake any reforms. This was an emergency regime. The second period, running from 1990 to 1995, represents the inception of the rule of law, with the adoption of the December 1990 Constitution by referendum. This was a time of liberalisation, marked by the adoption of a multiparty system and incipient public freedoms. Unfortunately, this period did not last very long. The ruling power organised and won presidential elections (1993) and parliamentary elections (1995), but both votes gave rise to strong protests, as a result of the massive electoral fraud. The third period is the period between 1996 and 2008. In February 1996, Lansana Conté faced the threat of being overthrown when a mutiny broke out in the armed forces, based on parochial demands. The head of state ended the mutiny by accepting all the demands, but he had many members of the forces arrested. This marked the restoration of an authoritarian regime. In November 2001, a referendum on the constitution led to the removal of the limitation on the number of presidential mandates and thus allowed Lansana Conté to stand for office indefinitely. In 1998, the president stood for re-election while the principal opposition candidate, Alpha Condé was arrested and imprisoned. The same occurred in 2003. In both of these elections, the head of state won the ballot, which the opposition condemned as fraudulent. A few months before, in 2002, the ruling majority had won the parliamentary elections under similar circumstances. With the exception of three parties, the opposition had chosen to boycott these elections.

Within such a context, there was little or no room for democratic forces to exercise oversight or control. The national assembly was considered a rubber stamp institution, in the service of the ruling government. In the socio-political arena, the ruling government did not hesitate to use deadly force on several occasions, in clamping down on trade unions and militant forces as they demanded social and political change (February, March and June 2006, January 2007).

A divided armed forces and the rivalry with security forces. The military was divided. It was often the theatre of generational conflict, ethnic tensions and personal rivalries, which resulted in the different groups of officers neutralising each other. Recruitment was based on political and ethnic criteria and training and exercises were inadequate; promotion did not depend on competence but rather on allegiance to the ruling power. There were huge disparities between the high-ranking officers, who were closest to the head of state and enjoyed 
great opulence, and the rank and file that lived in abject poverty. As a result, the indiscipline that had begun under Sékou Touré persisted in the barracks.

There was also an atmosphere of rivalry and mutual suspicion between the defence and security forces. This also applied between the military and the police because under Sékou Touré the military was subordinate to the Militia, the political police force. Being from the military, Lansana Conté directed more attention and resources to the gendarmerie than to the police, which is the security force that theoretically is responsible for protecting persons and goods. The police remained marginalised: their inferior role and status in the eyes of the army and gendarmerie led to violent clashes, most notably in June 2008 when police stations were destroyed. On 17 June 2008 for instance, soldiers clamped down violently on the police as they demanded increases in salaries and allowances.

\section{Security sector governance under Moussa Dadis Camara (2008-2009).}

President Conté officially died on the evening of 22 December 2008. His death was announced on national television at around one oclock in the morning by Aboubacar Somparé, the Speaker of the national assembly and the information was relayed by Prime Minister Souaré and the army chief of staff, General Diarra Camara. For a few hours, therefore, there was the feeling that the process set out under Article 34 of the Constitution ${ }^{6}$ to cover a vacancy of power had been initiated. The very next morning, however, at about 7.30am on 23 December, a group read out an initial statement over Guinean radio, announcing a putsch. Their spokesperson, Captain Moussa Dadis Camara announced the suspension of the constitution, government institutions and political and trade union activities, as well as the creation of a military committee known as the National Council for Development and Democracy (Conseil national pour la démocratie et le développement - CNDD). In the evening of 24 December he declared himself president of the republic.

Captain Camara himself announced the start of a political transition with clear objectives: to create the conditions that would enable Guinea to organise free and transparent elections and thus set up a democratic political regime through a democratic process of change (Bangoura, Bangoura \& Diop 2006). He promised not to stand for election himself in this process.

In reality, however, the situation quickly raised some fears. The government that was established by decree on 14 January $2009^{7}$ included a large majority of military officers. The 14 January 2009 programme statement appeared to be a vast undertaking, whereas the transition was only supposed to last a few months. Captain Camara would neither have the time nor the legitimacy to undertake all this, especially as the international donor community had condemned the putsch. 
The style of governance of the head of the junta was characterised by volte-faces, contradictory signals, populism and angry outbursts during which he would summarily dismiss officials in public and once shouted at a western diplomat. No institutions were established to manage the transition. The knell sounded on the transition during the sixth session of the International Contact Group for Guinea (ICG-G) on 3 and 4 September 2009 in Conakry. On that date, Moussa Dadis Camara operated an about-face, breaking his word and dispelling any hopes of calming the situation. In an aside to the attending diplomats he said, "I shall stand for election because the people are demanding that I do so".

This first transitional period was a failure. It ended with the bloodbath in the stadium in Conakry on 28 September 2009 where government defence and security forces violently repressed political party activists who were demanding an open and democratic electoral process. Another serious event occurred on 3 December 2009 when Captain Camara himself became the victim of an assassination attempt by the head of his personal guard. This was after Toumba Diakité had refused to comply with the instruction from the president to answer questions before the UN international commission of inquiry on the 28 September 2009 massacres. Did Toumba Diakite act because he feared prosecution or because as a matter of principle he felt that the head of state was ultimately accountable for the acts perpetrated? The situation is a further demonstration of the extent of violence and indiscipline within the armed and security forces in Guinea.

In conclusion, it is clear that since independence, the armed forces, gendarmerie and police (including the militia under Sékou Touré) in Guinea, have distinguished themselves with acts of violence and repeated exactions against civilians and their fellow citizens. These forces have shown the signs of recurrent deep-rooted dysfunctions, excessive politicisation and lack of discipline. This situation can essentially be attributed to the type of political regimes that have held power in the country; between 1958 and 2010 Guinea never experienced a democratic regime. In-depth reforms of security sector governance are thus absolutely indispensable in this context. With this in view, it is important to identify the conditions that will enable such changes; the challenges to be met or the obstacles to be overcome; the efforts to be encouraged and the transformational approaches to be supported.

\section{The conditions for change}

What conditions are required to bring about change in the political, military and security environments? What are the hindrances and the enabling factors? 


\section{The state of the administrative, legislative and judicial systems}

The issue is to determine what potential or real role can be played by the administrative system and the legislative and judicial branches of power in transforming or changing security sector governance. What possibilities can be developed in order to ensure effective separation of powers and a truly independent system of justice?

In Guinea, the administration is well known for being a tool of government and serves the ruling power. This has been demonstrated under every single government since the country attained independence. Far from being a neutral body, the administration serves the executive power. For example, under Lansana Conté, elections were organised by the government, in particular by the relevant ministries (local government and decentralisation, interior) in conjunction with the national electoral commission (1993), the high council in charge of electoral matters (1998) and the autonomous national electoral commission (2005), none of which were independent bodies. It was not until May 2007 that the national assembly adopted a draft bill establishing the Independent National Electoral Commission (Commission électorale nationale indépendante - CENI) (Bangoura 2007: 97). The CENI was a positive factor of change because it was, at least formally, the result of lengthy and difficult dialogue involving political parties (presidential majority and opposition) and government. In substance, the CENI was a novel institution that was supposed to be capable of organising and regulating the upcoming electoral process.

The establishment of the CENI by the national assembly can actually be considered quite an achievement because at the time the membership of the national assembly was not a true reflection of the entire political class. As a reminder, although parliamentary elections had taken place in 2002, most of the opposition parties had boycotted these elections, with the exception of the exception of three opposition parties. ${ }^{8}$ At the same time as it created the CENI, during its first session in May 2007, the national assembly adopted the law amending the electoral code, the law on financing political parties and the law governing the status of opposition parties. It also passed a bill establishing an independent national commission of inquiry charged with investigating the June 2006 and January-February 2007 massacres. ${ }^{9}$ Some of the factors that doubtless contributed to the passing of the bill include the weight of the prior democratic demands put forward by civil society and trade unions during the events in 2006 and 2007, which led to the 27 January 2007 tripartite agreement and the appointment of a consensus prime minister, Lasana Kouyaté, as head of government, in line with the terms of the agreement. ${ }^{10}$

Nevertheless, aside from these very important laws for the democratic process, the national assembly was unable in subsequent sessions in September 2007 and in 2008 to deal with defence and security issues that were still the 
preserve of the head of state General Lansana Conté. Although Article 59 of the constitution and its own by-laws allowed it to consider such matters, the national assembly was not yet familiar with the culture of democracy and did not enjoy sufficient independence to exert any control over government.

The justice system was no more independent than the rest. According to a Guinean lawyer, Mr. Thidiane Kaba, under Lansana Conté "the judiciary system was so subservient to the executive power that justice could not be properly administered" (Kaba 2007: 119) and the situation was compounded by the rampant corruption in the sector. The issue is not a lack of an institutional framework, because the December 1990 constitution does provide for the democratic rule of law, as well as the independence and smooth functioning of the justice system. The problem is the failure to apply the constitution, and in many cases the head of state was the first to infringe the fundamental law as, for example when he decided to personally travel to free his friend, the wealthy businessman Mamadou Sylla, from the prison where he had been incarcerated for embezzling public funds.

The same difficulties occurred under Moussa Dadis Camara who concentrated all powers in his own hands, with key ministries including justice being held by soldiers. Where the ministry of defence is concerned, the principle of civilian oversight over the military could not be applied since power was held by the junta. The national assembly, for its part, was dissolved at the time of the coup d'état. Captain Camara entrusted its role to the permanent secretariat of the CNDD, which was tasked with revising organic laws and the constitution, reforming the system of justice and supporting the reform of the defence and security forces. The secretariat was part of the junta and under the responsibility of a colonel who held the rank of minister.

It was only after the forum of militant forces of Guinea (civil society and political parties), meeting at the people's centre in Conakry on 12 March 2009, had put forward their demands and proposals that the principle of a transitional parliament known as the National Transitional Council (Conseil national de la transition - CNT) was reluctantly accepted, after lengthy negotiations. The practical establishment of this body was fraught with problems. A draft ordinance was submitted by the CNDD delegation during a visit to Brussels on 24 April 2009. This draft was rejected by the militant forces because it was not sufficiently independent of the junta. A new version was proposed by the minister and permanent secretary of the CNDD on 27 April. Based on this text, the militant forces negotiated with the CNDD early in May on the proposed CNT, outlining its mandate and the composition of its 163 members. The junta however subsequently amended the text unilaterally, increasing the number of members to 244 , to be able to include individuals that were devoted to their cause. It was only under the new political dispensation (Ouagadougou agreement) and the authority of General Sékouba Konaté that the CNT was finally established as a transitional body and was able to play its role. 


\section{Oversight mechanisms established, but limited}

Given the circumstances, it is clear that the system of governance under both Lansana Conté and Moussa Dadis Camara constituted an obstacle to change. Nevertheless a number of observation, oversight and control mechanisms were established under Lansana Conté, with the creation of the National Human Rights Observatory (Observatoire national des droits de l'homme - ONDH) in 2008 on the one hand, and the growing role played by civil society organisations on the other.

From the ONDH to the CNDH. In June 2008, a national human rights observatory was set up in Guinea, under the office of the prime minister. The institution was entrusted to the responsibility of Aliou Barry, a doctor of international public law and a professional in the area of defence and security matters, who was appointed by the prime minister on the basis of his competences. The ONDH was established a few months after the violent events of 2006 and 2007 during which the repression of demonstrations by trade unions and civil society resulted in a bloodbath. The ONDH, which was in charge of promoting human rights and ensuring their enjoyment, received the support of the United Nations. The establishment of the observatory was however not enough to prevent renewed human rights violations and the president of the institution was himself seriously injured ${ }^{11}$ by members of the armed forces and the presidential guard in the course of discharging his duties (Conakryka 2010). The regime thus did not allow the ONDH to carry out its functions properly.

It was not until May 2010 and the adoption of a new Constitution of the Republic of Guinea by the CNT that an "independent national human rights institution" was enshrined under Title XVI of the fundamental law (Guinea 2010: arts. 146, 148). ${ }^{12}$ Subsequently, President Alpha Condé created the National Human Rights Commission (Commission nationale des droits de l'homme - $\mathrm{CNDH})^{13}$ by decree dated 17 March 2011, soon after he was elected. Mamady Kaba, a civil society activist and former president of the Guinean chapter of the African Assembly for the Defence of Human Rights (Rencontre africaine pour la défense des droits de l'homme), was appointed president of the commission. The CNT then passed a bill establishing the organisation and functions for this independent national human rights institution on 14 July 2011. This institutional process aimed at improving the human rights situation was a major step forward, at least in formal terms.

The growing role of civil society organisations. It would not have been possible to create the $\mathrm{CNDH}$ without the sustained involvement of civil society and its lengthy advocacy. These activities were amply reported in the media. Civil society has gradually become more structured since 2002, culminating in a federation known as the National Council of Civil Society Organisations of Guinea (Conseil National des Organisations de la Société Civile Guinéenne - CNOSCG). 
It distinguished itself by mobilising to demand social and political change in 2006 and 2007. Since then, it has been unrelenting in fighting against impunity and in favour of respect for human rights. It played a predominant role in providing support to victims of the 2006-2007 and September 2009 massacres. It was able to collect eyewitness accounts and proof of the violence and cooperated with international organisations (United Nations High Commission on Human Rights, UN International Commission of enquiry, International Court of Justice, etc.) and international NGOs (International Human Rights Federation, Human Rights Watch, Amnesty International, International Crisis Group, etc.) working in this area.

In conclusion, it has been possible to initiate a movement for change in favour of security sector governance, with the drafting and adoption of new laws, improved establishment of an oversight and human rights promotion commission, civil society involvement in monitoring the activities and behaviour of defence and security forces and the partnership between national and international civil society organisations.

It is clear that the efforts of the $\mathrm{CNDH}$ and other non-governmental/civil society organisations must be encouraged because they represent a form of checks and balances; they provide a different view and understanding of the issues of insecurity, injustice and human rights violations. Very often, it is through dialogue and discussion of ideas, consultations, adversarial debate and monitoring and observation that they are able to have their voices heard and put forward proposals. In spite of the paucity of their operational resources and sometimes their inadequate representativeness, these organisations are generally keen to enhance their capacities and professionalism, which augurs well for their sustainability and effectiveness. One example is the involvement of civil society in the implementation of a project financed by the Peacebuilding Fund. ${ }^{14}$ The project, which aims to ensure civilian and democratic control of the defence and security forces, includes a component on capacity enhancement for civil society organisations.

This overall process is however not yet optimal, because of several obstacles related to the political violence that has held sway at the highest level of the state for more than 50 years, as well as the absence of a real political will to peacefully resolve the electoral dispute related to the preparation of parliamentary elections. These elections were postponed several times before they were finally held on 28 September 2013. Furthermore, to date, despite the progress made in civil-military relations, a strong feeling of mistrust still persists between the defence and security forces and the civilian population.

\section{A favourable political framework for change under the transitional leadership of General Sékouba Konaté}

Starting from January 2010, there were considerable improvements in security sector governance. This is understandable in the light of the situation at the time. The end of 2009 was a particularly trying time for Guineans. The 
massacres and gang rapes committed by forces of the Moussa Dadis Camara regime on the morning of 28 September 2009, followed by the assassination attempt on the head of state by the commander of the presidential guard on 3 December set off alarms throughout the country. In this instance, both the highest authority and those subject to authority had been affected. The violence had reached its paroxysm. The dysfunctions of the defence and security forces were at a peak.

While the vital forces of Guinea mourned their dead and cared for the injured, the UN International Commission of Inquiry sought to discern the truth regarding the 28 September 2009 massacres and to identify the perpetrators, in order that justice might be rendered. Militant forces called for protection from the international community in the form of a neutral force that could be interposed between the population and the DSF. They also called for an in-depth reform of the military and the police.

The Ouagadougou Joint Declaration (15 January 2010): a new framework for governance and security sector reform (SSR). In the absence of Moussa Dadis Camara, who was in hospital in Morocco, the second in line in the junta was in charge of expediting the affairs of State. This was General Sékouba Konaté, ${ }^{15}$ the minister of defence. He decided to meet with Moussa Dadis Camara as soon as the latter arrived in Burkina Faso for his convalescence, ${ }^{16}$ following the attempt on his life. The two men met on 13 and 14 January, in the company of the mediator, the Burkinabe president, Blaise Compaoré. At the end of their talks, they signed the Ouagadougou Joint Declaration on 15 January 2010. By this declaration, M. D. Camara officially conferred power to General Sékouba Konaté to govern during the transition. This declaration was obtained after strong pressure had been exerted by the militant forces of Guinea who approved the final draft, although they were not signatories.

This agreement comprised three points: it resolved the question of the succession; it set the principles and the roadmap for the transition (a six month transition to be used to organise presidential elections in which the present and former leaders would not participate) and set the reform of the defence and security forces as a priority. This was the first condition that marked the beginning of a transformation in security sector governance. From this point, other factors of change would apply.

General Sékouba Konaté holds the DSF accountable. One of the first measures taken by General Sékouba Konaté was to address the DSF and condemn the violent and barbaric acts perpetrated on the civilian population ${ }^{17}$ and on their chief, Captain Moussa Dadis Camara who was at the time the commander in chief of the armed forces. He also paid tribute to the memory of all the victims. This speech on 23 December 2009 and his visits to various barracks were widely covered by the media, while the campaign to educate the troops and officers and call them to account was seen as a welcome overture from the General and served to appease tensions somewhat in the country.

Evaluation of the security sector by the ECOWAS-UN-AU Joint Mission. ${ }^{18}$ The international community commended the president of the transition for his 
acts and offered its support in implementing the long-awaited reforms. The first of these was an evaluation of the various categories of actors in the security sector, as well as the sector as a whole. This exercise was carried out between 1 February and 30 April 2010 by a joint mission under the leadership of General Lamine Cissé, a well-renowned Senegalese officer both in his country and within the international community. The evaluation, which he carried out with a great deal of tact and professional experience, was the necessary starting point for any reform, as it provided a hitherto unknown picture of the security sector.

The evaluation report described the worrying state of deliquescence of the Guinean security sector where no standards had been applied for decades: totally disorganised defence and security forces, military interference in the political arena, absence of civilian control, a dysfunctional legal system and the involvement of non-state actors in security (militia, private companies). The report referred to the issue of the circulation of small arms and light weapons in the West African region, as well as other crosscutting issues such as gender. The report then made a series of recommendations under each of these points, at the end of a participatory process that took place in Conakry and other towns in the country.

The official report was submitted by the head of the joint mission to General Sékouba Konaté on 4 May 2010 during a ceremony at the Palais du peuple attended by the main socio-political actors in Guinea. These included representatives of government, the CNT, political parties, civil society, the security sector and external partners. Following the election of Alpha Condé, this report served as the reference document in preparing the SSR process in the country.

Early measures aimed at restructuring the DSF and the difference between restructuring and reform. From January 2010, after the signing of the Ouagadougou Agreement, General Sékouba Konaté initiated a vast restructuring exercise: imposing discipline and observance of the military hierarchy; a major project to construct new barracks; closure of the militia's Kaléah (Forécariah) training camp; a new military high command appointed by decree; recruitment of 8,000 trainee gendarmes to provide border security and ensure security during elections.

The restructuring exercise met an existing need and was warmly welcomed in the country. It however only represented a first step. The measures taken were technical and professional, aimed at bringing about functional improvements, but they did not tackle the root causes of the dysfunctions. They demonstrated the existence of a genuine political will to improve the living and working conditions of the defence and security forces, but fell short of overhauling the system. Furthermore, these measures were taken in isolation by the authorities, without taking account of the overall balance of numbers and without ensuring the participation of civil society.

Security sector reform is defined as both a policy and a holistic approach. Its aim is to establish highly performing defence and security institutions that 
are legally placed under the control of bodies enshrined in the constitution. It also aims to set up a strong and independent system of justice. In principle, reform must be carried out within a framework of national consultations. This is the type of reform that President Alpha Condé attempted to initiate when he acceded to power.

Establishment and role of the CNT. The ordinance establishing the CNT was signed by General Sékouba Konaté on 9 February 2010. Based on proposals by militant forces, the president of the transition appointed Hadja Rabiatou Serah Diallo, a trade union official, as head of this institution. On 17 February he sent a letter to the mission reminding them of the fact that the elections had to be organised within six months. The president of the CNT was invited to quickly set up the legislative body of the transition (101 members). The general indicated the quotas for each of these categories. ${ }^{19}$ The list of members of the CNT, who were appointed by presidential decree, was published on 7 March. ${ }^{20}$

The CNT was finally inaugurated during an official ceremony where the president of the transition made a solemn statement (L'Observateur 2010: 2). The CNT immediately got to work. Barely a week after being set up, it decided to create nine commissions, each responsible for a specific area: constitutional review, revision of texts governing elections, finances, treaties and laws, assessment of government activities, monitoring and evaluation of the CENI, national reconciliation, defence and security and communication. One of the leading tasks of the CNT was thus to review the fundamental law and the electoral code, in order to draft the constitution and appropriate texts for the elections.

Security of the electoral process. Unlike his predecessor, General Sékouba Konaté, the president of the transition, succeeded in rapidly setting up the institutions to manage this transition: a prime minister (Jean-Marie Doré, ${ }^{21}$ an opposition leader), a transitional national unity government, the national transitional council and the CENI (presided by Ben Sékou Sylla, a former president of the CNOSCG). General Sékouba Konaté officially took office in the middle of January 2010 and the first round of the presidential elections was held six months later, on 27 June. The president of the transition also ensured the security of electoral operations by passing a decree on 18 May 2010, establishing a combined force known as Special Force for a Safe Electoral Process (Force spéciale de sécurisation du processus électoral - FOSSEPEL), which was placed under the command of the army staff but under the authority of the CENI.

With the establishment of the CNT and the enhanced security of the presidential election, for the first time since independence the first round of democratic, open and transparent elections were successfully organised in Guinea. None of the leaders of the transitional institutions participated in these elections.

Unfortunately, the second round of the election did not take place until 7 November 2010. The delay was due to the moves to set up political alliances with the two remaining candidates, as well as other political manoeuvring. 
During this period between two rounds of voting, the 'demons' of exclusion and ethnic-based hatred reared their ugly heads once again and led to various incidents, heightened tensions and violence. Faced with accusations of fraud by the Union of Republican Forces, (Union des forces républicaines), the president of the transition, General Sékouba Konaté even threatened to resign on 6 July 2010. The incident was fortunately resolved quickly. The elections were finally won by Alpha Condé.

The transition had achieved its principal objective of putting in place a system of political governance that would restore the constitutional order. To achieve this, General Sékouba Konaté had displayed firm political will and maintained a steady course. Nevertheless, the atmosphere of political conflict that characterised the period between the two rounds of voting had left deep scars that would affect the way in which the new head of state would govern.

\section{The process of change since the election of Alpha Condé}

Strong political will and broad-based consultation. In his inaugural address on 21 December 2010, President Alpha Condé identified security sector reform as one of the priorities of his government programme and requested the assistance of the United Nations. To this end, in January 2011, a UN mission led by General Lamine Cissé drafted the initial technical documents based on the recommendations of the 2010 evaluation. Other experts from the United Nations Development Programme (UNDP) Bureau for Crisis Prevention and Recovery, the Geneva Centre for Democratic Control of Armed Forces, the United Nations Office for West Africa and the United Nations Department of Peacekeeping Operations were also deployed to provide technical assistance to the committee in charge of organising the planned national SSR seminar. ${ }^{22}$

The new head of state, who was also commander in chief of the armed forces and minister of defence confirmed his political will by personally opening and closing the national seminar on security sector reform on 28 and 31 March 2011, respectively. Another important factor of success for this seminar was the calibre and high number of participants; the president of the republic, representatives of government and state institutions, diplomats, international organisations (in particular the UN, AU, ECOWAS), civil society organisations, invited countries, regional military commanders and commanders of the major units in Conakry. During this meeting, participants identified priority measures and the timetable for implementing SSR in the short (2011), medium (2012) and long (2013 - 2015) term, for each sector. The report of the proceedings was published.

At the same time, a general assembly (états généraux) on the justice system was being held in Conakry under the patronage of the president of the republic, from 28 to 30 March 2011. The summary report reviewed the justice system 
and set three objectives. The first was to ensure an independent system through a reform of the higher council of magistrates, with the creation of disciplinary bodies, a career management plan for magistrates, salary increases and a statute for clerks of court. Next was the construction and equipment of courts and tribunals and finally the redesign of judicial constituencies to improve access to courts, as well as a review of the prison system.

On 14 April 2011, the president of the republic signed a decree establishing the national SSR steering committee. The committee, which was under his authority, was in charge of supervising the reform process, defining its political and strategic orientations and monitoring implementation. It comprised a programme management unit, a strategic orientation commission, a technical monitoring commission and sector-specific technical committees. This was the first stage in implementing the reform process. The committee was supported by the government of Guinea and assisted by the United Nations system in the country.

Shared objectives in SSR. The reform process emphasised a new concept of the defence and security forces as part of a comprehensive, inclusive, consensusbased and participatory approach. This depended on buy-in from all stakeholders and national ownership at every level. Right from the start, this reform process was part of a democratic renewal and the inception of true rule of law; it aimed to establish an independent, impartial, competent and accessible system of justice.

The main purpose of SSR was to put in place the appropriate institutional framework; to provide professional and operational capacities to the legal apparatus and the defence and security forces (military, gendarmerie, police-intelligence, civil defence, customs and the environment); to bring these services closer to the population; to ensure civilian control and to guarantee the enjoyment of human rights. The reform process also sought to contribute, through various crosscutting areas, to controlling transnational crime and the circulation of light weapons in the region. To a large extent, the Guinean population agreed with these objectives.

Implementation of SSR and civil-military rapprochement. Indeed, the citizens warmly welcomed the initial measures under the reform process. These included ensuring the security of the civilian population by enhancing discipline within the armed forces, improving the behaviour of military personnel, dismantling roadblocks and demilitarising the capital. Measures were then taken to restructure the forces on the basis of defence requirements. New units were created and the members of the former presidential guard and the battalion of airborne troops (Bataillon des troupes aéroportées - BATA) or the 'red berets' were redeployed and dispersed. Finally, steps were taken to create a rapprochement between the DSF and the population; the civil-military committee was revitalised and a department of Civic Service for Development (Service civique d'aide au développement) was established. was established. The basic 
documents of the reform process, in particular those related to the legal framework (legislative texts such as the code of military justice, the general statute and the military statute), as well as those on the organisational structure of the forces were drafted or revised by the competent departments.

The second phase of the reform process consisted of drafting a national SSR action plan. Each ministry was required to work, sector by sector, in five technical committees (Defence, Security, Justice, Customs and Environment). By the middle of 2012, this work had been completed and each sector had drafted its action plan. The sector policies have since been validated by the various ministries. The overall plan now has to be harmonised and consolidated, but this has not yet been done.

SSR advanced further in 2012 with the implementation of three projects; a biometric register of military personnel, retirement of 4000 military personnel and enhanced democratic and civilian control of the defence and security forces. UNDP recruited three experts to provide short-term technical assistance in these areas. The projects were financed by the United Nations Peacebuilding Commission Fund (PBC 2012).

Prospects of a national defence and security policy? On 23 August 2013, the deputy minister in charge of defence, Mr. Kabélé announced a new stage of SSR in Guinea, when he launched a national consultation throughout the regions, prefectures and communes of the country. The aim has been to involve all segments of the population in drafting the future national defence and security policy. This process is to be bottom up.

In the meantime, the United Nations system and technical and financial partners continue to support the SSR process. The European Union (EU) is providing assistance to three pilot projects on neighbourhood policing through the tenth European Development Fund. The aim is to bring the police closer to the population, to ensure more rapid access to security for individuals and to raise institutional awareness about police accountability. The EU is also providing support for civil defence (through the fire brigade in Conakry) and to the corps of forest rangers in high risk areas such as the Haute-Guinée park, the Ziama classified forest and the Mount Nimba protected area). ${ }^{23}$

All of the foregoing shows that SSR got off to a good start in 2011-2012, and progressed successfully because there was general consensus in the country on these matters. But can the pace be sustained?

\section{Roles of the various actors}

Various internal and external, institutional and more rarely, individual, actors constitute a driving force for SSR. It is however necessary to remain vigilant in certain cases because significant challenges persist. 


\section{Government and the challenge of policy dialogue and respect for human rights}

Following the November 2010 presidential election, the executive demonstrated its willingness and openness with regard to the need for security sector reform. The policy foundation for sound security sector governance was laid. However, within the context of Guinea, SSR can only truly be successful under the framework of democratic rule of law, which has not yet been restored in the country. The rule of law has been seriously undermined by more than half a century of bad practices. Although the various institutions have been set up, they are not truly functional and political tensions persist due to the manipulation of ethnic sentiment and the disputed results of the 2010 presidential vote.

One of the main challenges facing this government is establishing political dialogue $^{24}$ with the opposition. Both camps are still highly suspicious of one another because of the incidents of past presidential and parliamentary elections. Indeed, the latter were greatly delayed and only took place on 28 September 2013. The ruling authorities and opposition leaders have absolutely no trust in each other. As a result, the current government is unable to prevent the use of force during demonstrations, as was the case on 25 November 2013, when a young student died during a march organised by the opposition in protest against the results of the parliamentary elections published by the Supreme Court.

\section{From the CNT to the National Assembly: the end of the transition and the challenges of democracy}

The election of the members of the national assembly marked a major step forward. The new, democratically elected assembly was to replace the CNT. The final results proclaimed by the Supreme Court on 25 November 2013 confirmed the provisional results published by the CENI on 18 October; of the 114 seats in the national assembly, Alpha Condés party won 53, with 5 seats for his allies and 56 for the opposition. Although the ruling party had won, the opposition was well represented.

With the instauration of the new assembly the aim, in political terms, was to turn the page on the painful period of the transition, since the CNT was the only surviving institution of the transition, following the election of Alpha Condé. Guinea also needed to set up a true legislative body with the authority to ensure oversight of government activities. In the area of SSR, the new parliamentarians need to be educated and trained on civilian and democratic control of government. 


\section{A Reconciliation Commission but not Truth and Justice}

The Provisional Commission for National Reconciliation (Commission provisoire chargée de la réconciliation nationale) was established by presidential decree on 15 August 2011 and two religious personalities ${ }^{25}$ were appointed as co-presidents. It appears however that civil society was not adequately consulted on matters such as the mandate, powers and membership of the commission. The role of the commission appears to focus on reconciliation, but what about the 'truth' and 'justice' components that have characterised most truth and reconciliation commissions in Africa and in other parts of the world? Civil society would like the commission to deal with the question of impunity and make recommendations regarding the prosecution of individuals accused of perpetrating acts of violence.

The programme of action of the commission is divided into five phases: prayers, hearings, analyses based on the results of the work done at local, communal, district and national levels; defining orientations and finally setting up a body or institution in charge of national reconciliation.

After holding national and international consultations, the co-presidents of the Provisional Commission for National Reconciliation are expected to make proposals for the establishment of a real truth and reconciliation commission in Guinea. This is the fervent hope of civil society and some opposition leaders.

\section{The Office of the Ombudsman: a vital institution embodied by a controversial figure}

Title XI of the 2010 constitution, which was drafted and adopted by the CNT provides for the creation of an Office of the Ombudsman. Art. 127 describes the Ombudsman as "a body that intercedes, free of charge and independently, between the administration and the general public. According to the conditions established by law, it receives complaints from citizens relating to their interaction with government administrations, territorial constituencies, local authorities and public institutions, as well as any other bodies entrusted with a public service mission". The conditions for bringing a case before the Ombudsman, as well as the method of intervention and functioning of this body are set out by law.

While the creation of this institution is a welcome initiative, there have been concerns about the person selected to serve as ombudsman. In January 2011, President Alpha Condé appointed General Faciné Touré as the ombudsman. He was only able to take office in July, due to a controversy surrounding some comments that he had made which were considered inappropriate and likely to cause ethnic divisions. It is also important to note that this general was a former member of the Military Committee of National Recovery (Comité milit- 
aire de redressement national), the military committee that took over power in the wake of the coup by Lansana Conté.

It would appear that someone who generates consensus, who is demonstrably neutral and objective, has never held any political office in the previous authoritarian regimes and is selected for their competence would be a more appropriate choice for this position. Many such individuals can be found within the civil society.

\section{Role of external actors}

External parties such as the International Contact Group for Guinea (ICG-G) played an important political and diplomatic role in supporting the transition in Guinea, while some individuals such as General Lamine Cissé and also the various technical and financial partners played a decisive role in providing guidance and assistance in SSR.

The ICG-G was remarkable for its ability to support all stakeholders in the transition and also to provide renewed focus on the road map for the transition. It was also able to impose sanctions when peace and security in the country were under threat and there was a risk of human rights being violated. The group was set up by the international community in January 2009 in Addis Ababa, of an African Union meeting. ${ }^{26}$ The group met 17 times, at regular intervals, over a two year period between February 2009 and February 2011. The last meeting, which marked the end of its mandate and paved the way for the establishment of a group of the friends of Guinea, took place in Conakry on 10 February 2011, a few weeks after the newly elected president took office.

General Lamine Cissé is a retired Senegalese officer, who was instrumental in Guinea on several occasions starting from 2010, in providing advice, initiating, coordinating and monitoring the SSR process. He is well-renowned, in particular as a former minister of interior in his country, but also as the former Representative of the United Nations Secretary General and Head of the Office of the United Nations Organisation in the Central African Republic. His long years of experience, his interpersonal skills and his excellent knowledge of West Africa were valuable for this mission.

The technical and financial partners were the main bilateral and multilateral development partners of Guinea supporting SSR. These include France, the United States, the European Union and the Organisation internationale de la Francophonie. These external actors send civilian and/or military experts to the country to support the following areas respectively: department of Civic Service for Development (Service civique d'aide au développement); institutional capacity-building in security and SSR; justice system reform; and human rights training for military officers. 


\section{Conclusion}

The question now is whether the changes will continue. It must be recalled that the need for SSR had become vital for Guinea as a result of the conflictgenerating regimes and the violence that had prevailed since independence. SSR was however not possible under Lansana Conté because he prevented any attempts to implement reforms. The situation was the same under Moussa Dadis Camara. The first measures that foreshadowed a transformation in security sector governance and reform were introduced by General Sékouba Konaté. In a favourable political environment he demonstrated an unrelenting political will to begin restructuring the armed forces. He consented to the evaluation of the security sector and led the electoral process that resulted in a return to a constitutional order. The pre-requisite conditions for a veritable SSR process were put in place at that time.

The two first years of the Alpha Condé regime were very promising. The period from early 2011 to the end of 2012 was marked by a strong political will, openness and the search for a national consensus, followed by ownership and implementation, which were the first steps towards a real transformation of the security sector.

Throughout 2013, however, the process remained at a standstill. The main reason for this is the atmosphere of political conflict between the presidential majority and the opposition, as well as the violence that characterised the preparation and holding of parliamentary elections and the proclamation of the results. Furthermore, the fact that the process of drafting a national defence and security policy was initiated through consultation at the local and district levels could be interpreted as an attempt to postpone decisions and gain time. This inaction may be a government policy, until the reform can be resumed where it apparently stopped.

The initial enthusiasm has now subsided. The risk is that subsequently not enough attention will be focused on security sector reform. And yet the reform process, or rather the national SSR action plan has not yet been adopted, programmed, quantified or implemented. Quite an undertaking!

\section{Notes}

${ }^{1}$ After breaking with France, President Sékou Touré turned to the Soviet bloc and initiated civilian and military cooperation with Moscow and other allies of the Eastern countries.

${ }^{2}$ Sékou Touré wanted a docile military at the service of his regime and ready to execute his orders without asking questions. For him, the military, the party and everything that existed in Guinea was to serve to glorify his person (Bah 2009: 421). 
${ }^{3}$ Sékou Touré removed responsibility for the Deuxième Bureau (intelligence) from the military and entrusted the special service to his brother, Siaka Touré.

${ }^{4}$ According to Camara Kaba 41 (1998: 64), the prison known as 'Camp Boiro' was constructed by the Czechs in 1961 - 62 under the authority of Keita Fodéba, who was at the time the minster of Interior and Security, as well as the minister in charge of the Guinean People's armed forces.

${ }^{5}$ Despite being submissive to the regime, the military was not spared its tyranny: "obliged to blindly follow the orders of a single individual, the military largely assuaged the thirst for power... of the leader of the PDG throughout the twenty-six years of the revolution." Nevertheless, "some military leaders suffered the same fate as the victims that they tortured and killed before they themselves fell from grace" (Bah 2009: 153).

${ }^{6}$ Art.34 of the constitution stipulates that, "should the function of president of the republic fall vacant following the death or resignation of the incumbent..., the speaker of the national assembly or failing him, one of the deputy speakers, shall perform the function of president. Such vacancy shall be duly noted by the supreme court, which shall be informed by the speaker of the national assembly..." (translation by the author).

7 Passed on 14 January 2009, this decree appoints the members of government (Guinea 2009).

8 The three opposition parties that took part in the elections were: Union pour le Progrès et le Renouveau, Union pour le Progrès de la Guinée and the Parti du Peuple de Guinée.

9 This law was not unanimously welcomed because human rights defenders and representatives of the victims wanted an independent and possibly international commission of inquiry.

${ }^{10}$ Agreement signed on 27 January 2007 by unions, employers and governement, entitled Procès-verbal de négociations suite à la grève générale de l'Inter centrale syndicale CNTG-USTG élargie à l'ONSLG et à l'UDTG déclenchée le 10 janvier 2007.

${ }^{11}$ After the first round of the presidential election in June 2010.

${ }^{12}$ According to art. 146: "The independent national human rights institution is in charge of promoting and protecting human rights". Art. 148: "An organic law defining the membership, organisation and functioning of the institution".

${ }^{13}$ These names are reminiscent of French institutions: in France, the 'national human rights advisory commission is the national human rights institution, established in 1947'. In Africa, independent national human rights institutions are statutory bodies established by government and they are in charge of promoting and protecting human rights in their respective countries. These institutions must be created and function in accordance with the United Nations human rights promotion and protection principles 
(Paris Principles). Independent national human rights institutions are also required to assist the African Commission on Human and Peoples' Rights. Several African countries have established an independent national human rights institution. (Cameroon, Mali, Mauritius, Mauritania, Niger, Rwanda, Sierra Leone, South Africa, Togo, etc.) (CADHP 2015).

14 The Peacebuilding Fund is a fund for consolidating peace, which finances the projects of the United Nations Peacebuilding Commission (New York).

15 The December 2008 coup deétat was carried out by Captain Moussa Dadis Camara, who at the time worked at the army fuel depot, and Colonel Sékouba Konaté, Commander of the bataillon of the BATA, an elite unit. M. D. Camara had in the past served in the BATA. The two men knew each other well and were friends. M.D. Camara promoted Sékouba Konaté to the rank of general in January 2009.

${ }^{16}$ Moussa Dadis Camara was initially evacuated to Morocco for treatment. Subsequently, in the evening of 12 January he arrived in Burkina Faso, the home of the mediator in the Guinean crisis, where he was to continue his convalescence.

17 General Sékouba Konaté could speak out against these acts because on 28 September 2009 he was away from the country on a mission. He was therefore not involved in the massacres.

18 Other participants in this joint mission included bilateral and international partners such as France and the United States, the European Union and the Organisation internationale de la Francophonie.

19 The Ouagadougou Joint Declaration provided for 101 members, distributed as follows in the Mission Letter: 30 (political parties), 15 (unions), 9 (civil society) 8 (external), 3 (professional orders), 4 (regional coordination units), 10 (defence and security forces), 2 (human rights), 4 (youth), 3 (employers), 3 (private media), 4 (women), 2 (farmers' organisations), 2 (craftsmen's organisations), 2 (religious bodies).

20 To their great surprise, the people of Guinea realised that the decree (Guinea 2010b) had increased the number of members from 101 to 155.

21 Jean-Marie Doré was appointed as prime minister by decree by General Sékouba Konaté on 19 January 2010 and he took up office on 26 January after a hand over ceremony with Kabiné Komara. In a brief address, the new prime minister indicated that his two main missions would be the elections and an overhaul of the military. This was a way of demonstrating that he had properly understood his duty as the head of the new transitional government.

22 The national SSR seminar was organised with funding from the UNDP and technical and logistical assistance from the United Nations system in Guinea.

${ }^{23}$ See further, e.g., the press release of the European Union delegation to Guinea (Délégation de l'Union européenne en Guinée 2013). 
24 Various fora on political dialogue have been organised with the support of the international community (UN-ECOWAS-Organisation internationale de la Francophonie-EU-France-United States): Inclusive political dialogue, which was held in Conakry from 27 December 2011 to 22 February 2012, followed by Inter-Guinean Dialogue, also in Conakry from 5 to 9 June 2013 and on 2 and 3 July 2013, to try to arrive at an agreement on the preparation and holding of parliamentary elections.

25 Mgr Vincent Koulibaly, Archbishop of Conakry and El Hadj Mamadou Saliou Camara, Imam of the Fayçal mosque in Conakry.

${ }^{26}$ Members of the ICG-G included: the United Nations, the African Union, the European Union, the Organisation internationale de la Francophonie, the Economic Community of West African States (ECOWAS), the Mano River Union, the Organisation of Islamic Conference, the Community of Sahel-Saharan States, the World Bank, Angola (as chair of the African Union Peace and Security Council) Nigeria (as president of ECOWAS), as well some African States (Burkina Faso, in charge of the mediation), the permanent members of the United Nations Security Council (the United Kingdom, France, Russia and the United States of America), Spain and finally Morocco (January 2010). Côte d'Ivoire, Ghana, Guinea-Bissau, Mali and Senegal also took part in the group. 